\title{
About rats and jackfruit trees: modeling the carrying capacity of a Brazilian Atlantic Forest spiny-rat Trinomys dimidiatus (Günther, 1877) - Rodentia, Echimyidae - population with varying jackfruit tree (Artocarpus heterophyllus L.) abundances
}

\author{
Mello, JHF. ${ }^{a, b *}$, Moulton, TP. ${ }^{c}$, Raices, DSL. ${ }^{d}$, Bergallo, HG. ${ }^{b}$ \\ aPrograma de Pós-Graduação em Ecologia e Evolução - PPGEE, Universidade do Estado do Rio de Janeiro - UERJ, \\ Rua São Francisco Xavier, 524, Pavilhão Haroldo Lisboa da Cunha - PHCL, CEP 20550-013, Rio de Janeiro, RJ, Brazil \\ 'Laboratório de Ecologia de Mamíferos - LEMA, Departamento de Ecologia - DECOL, Instituto de Biologia Roberto \\ Alcântara Gomes - IBRAG, Universidade do Estado do Rio de Janeiro - UERJ, Rua São Francisco Xavier, 524, \\ Pavilhão Haroldo Lisboa da Cunha - PHLC, CEP 20550-013, Rio de Janeiro, RJ, Brazil \\ 'Laboratório de Rios e Córregos, Departamento de Ecologia - DECOL, Instituto de Biologia Roberto Alcântara \\ Gomes - IBRAG, Universidade do Estado do Rio de Janeiro - UERJ, Rua São Francisco Xavier, 524, Pavilhão Haroldo \\ Lisboa da Cunha - PHCL, CEP 20550-013, Rio de Janeiro, RJ, Brazil \\ 'Instituto Chico Mendes de Conservação da Biodiversidade - ICMBio, EQSW 103/104, Bloco C, \\ Complexo Administrativo, Setor Sudoeste, CEP 70670-350, Brasília, DF, Brazil \\ *e-mail: mello.jhf@gmail.com
}

Received: July 4, 2013 - Accepted: October 11, 2013 - Distributed: March 31, 2015

(With 3 figures)

\begin{abstract}
We carried out a six-year study aimed at evaluating if and how a Brazilian Atlantic Forest small mammal community responded to the presence of the invasive exotic species Artocarpus heterophyllus, the jackfruit tree. In the surroundings of Vila Dois Rios, Ilha Grande, RJ, 18 grids were established, 10 where the jackfruit tree was present and eight were it was absent. Previous results indicated that the composition and abundance of this small mammal community were altered by the presence and density of $A$. heterophyllus. One observed effect was the increased population size of the spiny-rat Trinomys dimidiatus within the grids where the jackfruit trees were present. Therefore we decided to create a mathematical model for this species, based on the Verhulst-Pearl logistic equation. Our objectives were i) to calculate the carrying capacity $\mathrm{K}$ based on real data of the involved species and the environment; ii) propose and evaluate a mathematical model to estimate the population size of $T$. dimidiatus based on the monthly seed production of jackfruit tree, Artocarpus heterophyllus and iii) determinate the minimum jackfruit tree seed production to maintain at least two T. dimidiatus individuals in one study grid. Our results indicated that the predicted values by the model for the carrying capacity $\mathrm{K}$ were significantly correlated with real data. The best fit was found considering $20 \sim 35 \%$ energy transfer efficiency between trophic levels. Within the scope of assumed premises, our model showed itself to be an adequate simulator for Trinomys dimidiatus populations where the invasive jackfruit tree is present.
\end{abstract}

Keywords: ecological modeling, exotic species, Brazilian Atlantic Rainforest, jackfruit tree seed production, VerhulstPearl logistic equation.

\section{Sobre ratos e jaqueiras: modelando a capacidade suporte de uma população do rato-de-espinho da Mata Atlântica Trinomys dimidiatus (Günther, 1877) - Rodentia, Echimyidae - em relação a diferentes abundâncias de jaqueiras (Artocarpus heterophyllus L.)}

\section{Resumo}

Realizamos um estudo de seis anos para avaliar se e como uma comunidade de pequenos mamíferos terrestres da Mata Atlântica respondia à presença da jaqueira Artocarpus heterophyllus, espécie possivelmente nativa da Índia. Nos arredores da Vila Dois Rios, Ilha Grande, RJ, nós estabelecemos 18 grades de estudo, sendo 10 com jaqueiras e oito sem jaqueiras. Resultados prévios indicaram que a composição e a abundância dessa comunidade de pequenos mamíferos foram alteradas pela presença e densidade de A. heterophyllus. Um dos efeitos observados foi o aumento das populações do rato-de-espinho Trinomys dimidiatus nas grades onde a jaqueira estava presente. Criamos um modelo matemático para prever a capacidade de suporte dessa espécie, baseado na equação logística de Verhulst-Pearl. Nossos objetivos 
foram i) calcular a capacidade de suporte $\mathrm{K}$ com base em dados reais coletados tanto para T. dimidiatus quanto de seu ambiente; ii) propor e avaliar um modelo matemático para estimar o tamanho populacional de T. dimidiatu baseado na produção mensal de sementes de jaqueira e iii) determinar a produção mínima de sementes de jaqueira necessária para manter pelo menos dois indivíduos de T. dimidiatus. Nossos resultados indicaram que os valores previstos para $\mathrm{K}$ gerados pelo modelo foram significativamente correlacionados com os dados reais coletados. O melhor ajuste foi obtido considerando uma eficiência de transferência de energia entre níveis tróficos entre 20 e $35 \%$. Dentro do escopo das premissas assumidas, nosso modelo se mostrou um simulador adequado para populações de T. dimidiatus em áreas onde a jaqueira já tenha invadido.

Palavras-chave: modelagem ecológica, espécies exóticas invasoras, Mata Atlântica brasileira, produção de sementes de jaqueira, equação logística.

\section{Introduction}

Biological invasions are one of the major causes for human-mediated biodiversity loss, along with habitat loss and species over-exploitation (Phillips, 1997; Williamson 1999). The invasion process, however, is not simple - and normally not easy - for introduced species, and only a minority of species actually becomes established (Williamson and Fitter, 1996; Colautti and MacIsaac, 2004; Pyšek and Richardson, 2010). Those that do become invasive, however, may cause severe changes in their new habitats. The impairment of native community dynamics may result in biodiversity loss (Mooney and Cleland, 2001; Aizen et al., 2008; Vilà et al., 2011) and biotic homogenization (McKinney and Lockwood, 1999), which in turn may facilitate new invasions (Simberloff and Von Holle, 1999; Prenter et al., 2004). This may be the case of the jackfruit tree, Artocarpus heterophyllus Lam. (Moraceae), in the Brazilian Atlantic Forest.

In order to understand how the presence of Artocarpus heterophyllus may disrupt the dynamics of Atlantic Rainforest communities, the Mammal Ecology Laboratory of Universidade do Estado do Rio de Janeiro has been monitoring a small mammal community in a Southeastern Brazilian Atlantic Forest since 2006. The data gathered showed that the small mammal community is indeed affected by the presence and abundance of the jackfruit tree, with frugivore species seemingly benefiting from it (Raíces et al., in preparation). One example of this effect is the population increment of the Brazilian Atlantic Forest spiny-rat Trinomys dimidiatus in areas where A. heterophyllus is present (Raíces et al., in preparation). It is important to be able to estimate the extent of this population increment in areas already invaded, because herbivores play important roles in forest regeneration and seed dispersal dynamics. However, as Asquith et al. (1997) showed, these effects are directly related to herbivore density. In their study on Panamanian Moist forests, in the absence of top chain predators, granivore density increases, negatively affecting seedling recruitment. Therefore, in order to generate a rough estimate of how A. heterophyllus may be influencing Trinomys dimidiatus in areas already invaded by $A$. heterophyllus, we decided to test a simple model, based on the logistic growth equation.

Although the usage of the logistic growth equation is widely disseminated in ecology, the definition of what actually is carrying capacity is still somewhat dubious. Carrying capacity is, in essence, the limiting factor which controls the maximum density. Therefore, independent of the adopted definition, it should always be viewed as a result of the interaction of the characteristics of both the environment and the species being studied. One consequence of this view is that, when the limiting factor is a consumable resource, e.g. available water, carrying capacity is related to both the metabolism of the studied species and the total production of that habitat.

In 1925, the geographer Albrecht Penck (apud Cohen, 1995) considered similar statements trying to estimate the carrying capacity of human population with the formula presented in Equation 1:

$$
\text { Population that can be fed }=\frac{\text { food supply }}{\text { individual food requirement }}
$$

However, according to Cohen (1995), when trying to estimate the maximum human population, it is necessary to take into account that human feeding habits are not based in alimentary items freely found in nature anymore. Factors such as available area for food production, the need water for that production, what may, culturally, be classified as food and even technological improvements to increase production must be considered. However, for species with limited capacity for changing the surrounding environment, we believe that Penck's formula may be used to assess the carrying capacity K. It is important to note that, by applying Penck's formula, the ecological parameters included in the model are kept at minimum level. Our model disregards several variables that, in the real world, may have different levels of influence on population and community structure and dynamics. However, here we will show that for Trinomys dimidiatus present in areas invaded by Artocarpus heterophyllus, the jackfruit tree seed production is a major estimator for possible population increase.

Therefore, the objectives of the present study were to i) calculate the carrying capacity $\mathrm{K}$ based on real data of the characteristics of the particular species and its environment; ii) propose and evaluate a mathematical model to estimate the population of $T$. dimidiatus based on the monthly seed production of jackfruit tree, Artocarpus heterophyllus and iii) determinate the minimum jackfruit tree seed production to maintain at least two $T$. dimidiatus individuals in one study grid. 


\section{Material and Methods}

\subsection{Study site}

The study area is located in the surroundings of Vila Dois Rios, on the oceanic side of Ilha Grande $\left(23^{\circ} 05^{\prime}-\right.$ $23^{\circ} 15^{\prime} \mathrm{S}$; $\left.44^{\circ} 05^{\prime}-44^{\circ} 23^{\prime} \mathrm{W}\right)$, which is an island located in the southeastern coast of Rio de Janeiro state, Brazil. Ilha Grande has an area of 19300 ha and mean annual precipitation ranging from $1515 \mathrm{~mm}$ to $2200 \mathrm{~mm}$ with no month with a deficit of evaporation over precipitation (Esbérard et al., 2006). More than 50\% of its territory is covered by Dense Rainforest formations, in different successional stages (Oliveira, 2002). It can also be found secondary forests, rocky herbaceous vegetation, Restinga vegetation and Mangroves (Alho et al., 2002). The human presence at Ilha Grande is ancient ( $c a 3000$ years, Oliveira, 2002). It experienced most Brazilian economic cycles, such as the selective removal of Brazil wood - Caesalpinia echinata L. - on the arrival of European settlers in early XVI century (Esbérard et al., 2006), and sugarcane and coffee plantations in middle XVIII century (Oliveira, 2002). According to Alho et al. (2002), Ilha Grande was also an important slave trade entry port. It was only in the late 1970 s that farms were disabled, concomitantly with the establishment of Ilha Grande State Park.

\subsection{Data gathering}

The data related to the modeled species-Artocarpus heterophyllus and Trinomys dimidiatus - was collected from July 2006 to October 2009. In July 2006, 18 grids, each $40 \times 40 \mathrm{~m}$, were established in the surroundings of Vila Dois Rios, 10 where the jackfruit tree was present and eight where it was absent. Each grid was identified with a two letter code: the first letter defined if the A. heterophyllus was present ("C" grids) or absent ("S" grids), and the second letter identified the grid (i.e. CA stands for the first grid where $A$. heterophyllus is present, while $\mathrm{SH}$ is the last grid where it was absent). Each grid was trapped every two months with 11 live capture traps. The bait used was always banana. Each captured individual was ear-tagged with a unique code number in order to avoid counting the same individual twice in the same field campaign.

\subsection{Studied species}

The jackfruit tree (Artocarpus heterophyllus L.) is possibly indigenous to the rainforests of India (Zerega et al., 2005; Shyamalamma et al., 2008), being found throughout southeastern Asia, although this distribution may be partially due to intentional plantation (Rahman et al., 1995; Zerega et al., 2004). In Brazil, however, A. heterophyllus was introduced during Brazilian colonial times, circa XIX century (Abreu and Rodrigues, 2010).

The jackfruit tree is a shade tolerant species, although it needs fair amounts of light during its early life stages (Khan, 2004). It bears fruits almost year round, with a peak between July and August in its native range and between October and March in Atlantic Rainforest (Abreu and Rodrigues, 2010; D.S.L. Raíces, personal communication). An adult individual may produce about 100 fruits per year, each fruit weighing up to 30 kilograms. Currently, the jackfruit tree can be found in almost all Brazilian territory, and is commonly associated with human-influenced environments. In Rio de Janeiro state, Artocarpus heterophyllus forms dense colonies in forest edges and clearings of Atlantic Rainforest, and is easily found in some protected areas such as Tijuca National Park (Abreu and Rodrigues, 2010) and Ilha Grande State Park.

According to Khan (2004), mammals, such as rodents, wild pigs and primates, are the main dispersers of A. heterophyllus in India, although its seeds are subjected to relatively high levels of predation (Sodhi et al., 2003). In Brazil, there are at least 701 mammalian species, distributed among 12 orders (Paglia et al., 2012). Following worldwide patterns, the most diversified subgroup are the so-called small mammals (Fonseca, 1989; Pardini and Umetsu, 2006), which are defined as weighing less than $3 \mathrm{~kg}$ (Prevedello et al., 2008). Most Brazilian non-volant small mammals are in Didelphimorphia (Marsupialia) and Rodentia (Eutheria).

Because of their high species richness, relatively high densities and wide variety of habits (Prevedello et al., 2008), small mammals are commonly considered good models for understanding ecological patterns of endemism (Ceballos and Brown, 1995; Bonvicino et al., 2002) and macroecology (Vieira and Diniz-filho, 2000), and for understanding the dynamics of communities (Carvalho et al., 1999; Castro and Fernandez, 2004; Ribeiro and Marinho-Filho, 2005), processes of zoonosis transmission (Lemos et al., 2004; Pinto et al., 2009), seed dispersal and forest regeneration (Pardini et al., 2005; Jordano et al., 2006). The last are particularly important processes for tropical forests, since it is estimated that in these environments, about $50 \%$ to $90 \%$ of tree species are dispersed by animals (Jordano et al., 2006).

The Brazilian Atlantic forest spiny-rat Trinomys dimidiatus (Günther, 1877) has terrestrial habits, a body length ranging from 180 to $220 \mathrm{~mm}$, tail length ranging from 150 to $195 \mathrm{~mm}$ and body mass between 180 and 227 g (Bonvicino et al., 2008). According to Vieira et al. (2003) congener species $T$. ihering $i$ was observed consuming seeds and fruits regardless of their sizes. Our own data indicate that the diet of $T$. dimidiatus is similar to that observed for $T$. iheringi. The mean abundance of $T$. dimidiatus in each area was calculated as the total number of captures divided for the total amount of field campaigns.

\subsection{Calculating the carrying capacity}

The carrying capacity K was assessed with Equation 1. In the present study "food supply" equates to the monthly amount of seed produced in each grid, while "individual food requirement" is the daily amount of jackfruit tree seeds consumed by one $T$. dimidiatus individual.

In order to use this equation, some premises were assumed:

i) Each grid is absolutely isolated from the others;

ii) Each grid has its own population, where migration is not allowed; 
iii) $T$. dimidiatus population is not affected by any environmental variable other than resource fluctuation;

iv) The only available resource in the grids where A. heterophyllus is present is jackfruit tree seeds;

v) Any individual that does not consume resources, will necessarily die;

vi) The fruit and seed production are constant, and equal to the annual mean production, equally distributed among 12 months. Therefore, it is not affected by $T$. dimidiatus density.

The three first premises were assumed in order to make our modeled population match the "closed population" definition given by Seber (1973). This is necessary not only to limit the active environmental variables in our model - this being the seed production - but also to match our modeled population to the real population. Premise number $\mathrm{v}$ was assumed in order to match "population that can be fed" to the carrying capacity K. It is also important to highlight that "individual food requirement" is a directly proportional response to the individual energy expenditure. Thus, "individual food requirement" may be assumed to be a function of individual metabolism and therefore may be directly calculated from the species metabolic rates. In this work we decided to use the basal metabolic rate (BMR).

The BMR for Trinomys dimidiatus was assessed via a linear approximation based on available data in the literature for Rattus rattus (Forsum et al., 1981), since mean body mass of both species is similar. The allometric exponent used by Forsum et al. (1981) was $3 / 4$.

It is also important to note that if we do not consider the energy transfer efficiency between trophic levels, one would have to assume that this value oscillates near $99 \%$. Although there are few studies comparing the energy transfer efficiency in terrestrial environments, Pauly and Christensen (1995) estimated the mean efficiency at $10,13 \%$ in aquatic environments. Thus, in our model we assumed a scenario where only $10 \%$ of the total energy stored in the jackfruit tree seeds would be promptly available. The amount of calories present in the seeds was estimated based on the values provided in the $4^{\text {th }}$ edition of the Brazilian Table of Food Composition for a portion of $100 \mathrm{~g}$ of raw jackfruit - 88kCal (368kJ) - Tabela Brasileira de Composição de Alimentos (NEPA, 2011). Since each jackfruit carries a minimum of 100 seeds (pers. obs.), the jackfruit tree minimum seed production was calculated as 100 times the mean monthly fruit production for each grid.

\subsection{Mathematical model}

As the basis of our model, we assumed a logistic growth for Trinomys dimidiatus, following Verhulst-Pearl's equation (Equation 2):

$$
\frac{d \mathrm{~N}}{d \mathrm{t}}=\mathrm{rN}\left(1-\frac{\mathrm{N}}{\mathrm{K}}\right)
$$

Where $\mathrm{dN} / \mathrm{dt}$ is the population growth, $\mathrm{r}$ is the intrinsic growth rate; $\mathrm{N}$ is the population size and $\mathrm{K}$ environmental carrying capacity. Following the values found by Bergallo
(1995) for the congener species T. iheringi, we established an initial population of $\mathrm{N}_{0}=0.85$ individuals for all grids. The intrinsic growth rate was obtained in literature for congener species T. iheringi and T. eliasi. Bergallo (1996) calculated the intrinsic growth rate for T. iheringi in Ilha do Cardoso as $r=0.22$ per month, using the body mass formula proposed by Caughley and Krebs (1983), while Brito and Figueiredo (2003) obtained a similar value for T. eliasi $(\mathrm{r}=0.287$ per month) in Barra de Maricá, using the software Vortex $8.21^{\circledR}$. To evaluate if and how much the values generated by the model approach the actual field data, we tested Pearson's correlation coefficient with Bonferroni's probability. All statistical tests were made in Systat $11^{\circledR}$. Figures 1 and 2 were made in Systat $11^{\circledR}$ and Figure 3 was made in Excel $2007^{\circledR}$.

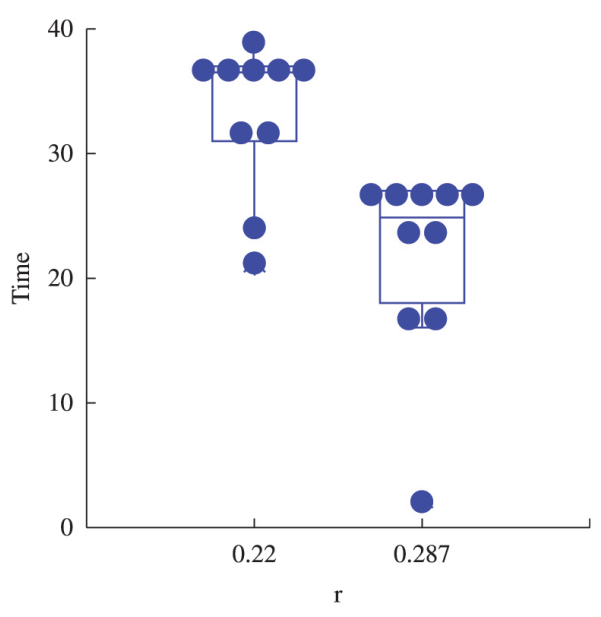

Figure 1. ANOVA between $\mathrm{r}=0.22$ and $\mathrm{r}=0.287$. The needed time for the Trinomys dimidiatus populations to reach K, assuming $r=0.22$ and $r=0.287$, were statistically different $(\mathrm{p}=0.002)$.

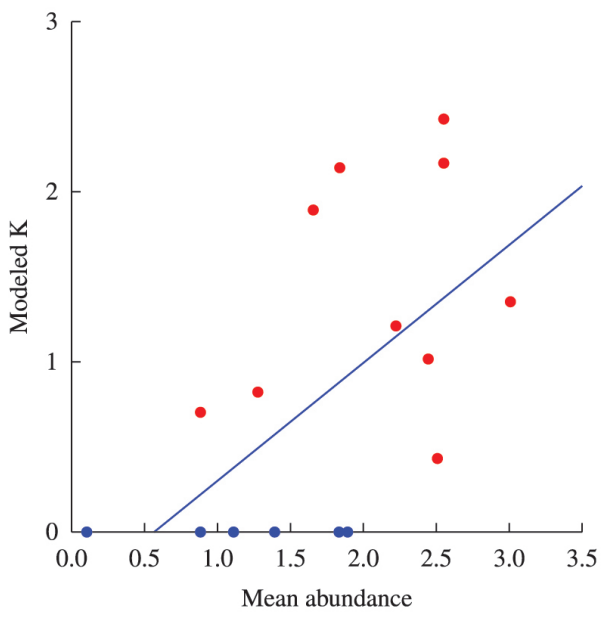

Figure 2. The population size values projected by the proposed model were statistically correlated with actual values $(r=0.596, p=0.009$, Pearson's coefficient). The areas with jackfruit trees are represented by red dots and the areas without jackfruit trees by blue dots. 


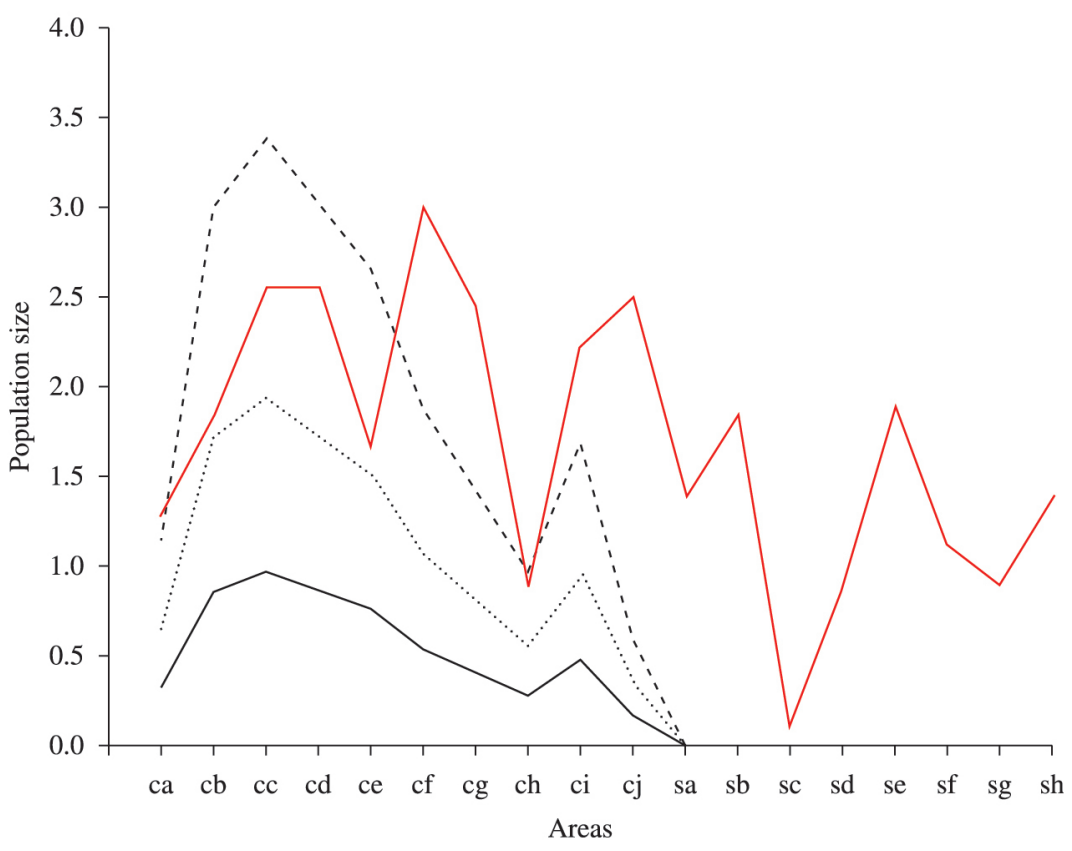

Figure 3. Population size in each grid, for both field-gathered and modeled data. The mean population size for Trynomys dimidiatus (red continuous line) varied between 3 and 0.11 individuals. The carrying capacity $\mathrm{K}$ for $10 \%$ energy transfer efficiency (continuous black line) varied between 0.97 and zero, between 1.94 and zero for $20 \%$ energy transfer efficiency (dotted line) and between 3.39 and zero for 35\% energy transfer efficiency (dashed line). Areas initiated by "c" indicate areas with jackfruit trees, while areas initiated with "s" indicate areas without jackfruit trees.

\section{Results}

The number of adult jackfruit trees varied between 5 and 48 individuals per grid. Consequently, the calculated seed production varied between 472 and 1590 seed/ month. Since the mean mass of a jackfruit tree seed in the surroundings of Vila Dois Rios was $2.5 \mathrm{~g}( \pm 0.616 \mathrm{~g}$, $\mathrm{N}=100$ ), the amount of energy contained in one seed was calculated as $2.2 \mathrm{kCal}(9.21 \mathrm{~kJ})$.

For Rattus rattus, Forsum et al. (1981) found a BMR of $80,8 \mathrm{~kJ}( \pm 3.8 \mathrm{~kJ}) / 22 \mathrm{~h}$ in animals with a mean body mass of $337 \mathrm{~g}( \pm 8 \mathrm{~g})$. Thus, the BMR for Trinomys dimidiatus with a mean body mass of $217 \mathrm{~g}( \pm 32.38 \mathrm{~g})$ was 12.03 $\mathrm{kCal} /$ day $(50.35 \mathrm{~kJ} /$ day).

In order to evaluate the time needed for the populations to stabilize, we tested the values of intrinsic growth rate observed by Bergallo (1995) for T. iheringi $(\mathrm{r}=0.22)$ and Brito and Figueiredo (2003) for T. eliasi $(\mathrm{r}=0.287)$. For $\mathrm{r}$ $=0.22$, the mean needed time for all the populations reach $\mathrm{K}$ in all areas was $33.2 \pm 6.2$ months, while for $\mathrm{r}=0.287$ this time was $21.6 \pm 7.9$ months. This difference was statistically significant $(\mathrm{p}=0.002)$ (see Figure 1). This analysis was done only with the areas where the jackfruit trees were present.

The higher value for the mean abundance of $T$. dimidiatus was 3 individuals in a grid with jackfruit trees (CF) and the lowest value was 0.11 in a grid without jackfruit trees (SC). The projected values for the carrying capacity $\mathrm{K}$ varied between 0.97 (in the grid with jackfruit trees CC) and zero in all grids without jackfruit trees, considering $10 \%$ energy transfer efficiency K. However these values underestimated the real data values and a better adjustment of the model was found between 20 35\% energy transfer efficiency (see Figure 3). The projected values for $\mathrm{K}$ and real data gathered for the studied population of $T$. dimidiatus were significantly correlated $(r=0.596, p=0.009$, see Figure 2$)$. The values generated by the model for the mathematical manipulation of jackfruit tree seeds showed that the minimum seed production needed in order to maintain a population of at least two individuals of T. dimidiatus is approximately 3300 seeds/month. In terms of fruit production, this value corresponds to 33 jackfruits/month. Considering the mean jackfruit monthly production in our area of study, the presence of 3.97 adult individuals would be sufficient to maintain those two $T$. dimidiatus individuals.

\section{Discussion}

Our data indicated that, within the universe generated by our assumed premises, our model adequately predicted the maximum abundance of the studied Trinomys dimidiatus population. The values estimated by the model for the carrying capacity K of our studied grids were significantly correlated with this species' observed densities. This shows that the predicted variations on the density of $T$. dimidiatus occur in a similar fashion of those observed in the real data, even though the matching between the real data and the modeled data is not perfect.

The observed differences between actual data and the data provided by the model arise from the assumptions made during the construction of the model. We believe to 
be interesting and instructive to make some considerations about it. First, although our own data indicate that T. dimidiatus has some territorial tendencies, as observed by Bergallo (1995) for T. iheringi females, there are no physical barriers that would actually prevent migration from a grid to an adjacent grid. This is especially true for young and sub-adults individuals that are not residents within the grids (Bergallo, 1995). Second, we estimated the BMR of T. dimidiatus as a linear approximation, based on the data of Forsum et al. (1981) for Rattus rattus. It is important to consider that, although the mean body mass of $T$. dimidiatus and $R$. rattus is close, some studies suggest that feeding habits may have a significant influence on mammalian BMR (McNab, 1986; Bozinovic et al., 2007). Finally, 10\% trophic level energy transfer efficiency did not provide a good fit between the model and the real data. A better fit was found between 20 and 35\% energy transfer efficiency, which is a remarkably high value for transfer efficiency when compared with literature (e.g. Pauly and Christensen, 1995; Ernest et al., 2003). However, it must be noted that most studies which examine energy transfer efficiencies do so in aquatic environments and the canonical $10 \%$ value may not necessarily apply (Slobodkin, 2001).

Taking these in consideration, our model describes reasonably well the studied population, in Atlantic forest areas where the jackfruit tree is present. This raises the possibility of using our model as a base for estimating the benefits and impacts of the invasive Artocarpus heterophyllus in other areas. Even if A. heterophyllus brings benefits to $T$. dimidiatus, the same cannot be said for all the small mammal species present. This is particularly true for insectivore species such as the rodent Oxymycterus dasytrichus, which has its abundances reduced in areas where the jackfruit tree is present (unpublished data). As for future refinements, still disregarding stomach content analysis as a viable option, it may be possible to estimate the food production by using the proportion of each alimentary item found in the feces.

\section{Acknowledgements}

We are thankful to CEADS and UERJ/SR-2 for logistic and infrastructure support. We also would like to thank one anonymous reviewer for the useful comments in an earlier version of this manuscript. JHFM thanks CAPES for the post-graduate scholarship. HGB and TPM thank CNPq and Prociência/UERJ for the research fellowship. This study was supported by FAPERJ and CNPq grants.

\section{References}

ABREU, RC. and RODRIGUES, PJF., 2010. Exotic tree Artocarpus heterophyllus (Moraceae) invades the Brazilian Atlantic Rainforest. Rodriguésia, vol. 61, no. 4, p. 677-688.

AIZEN, MA., MORALES, CL. and MORALES, JM., 2008. Invasive mutualists erode native pollination webs. PLoS Biology, vol. 6, no. 2, p. e31. http://dx.doi.org/10.1371/journal.pbio.0060031. PMid:18271628
ALHO, CJR., SCHNEIDER, M. and VASCONCELLOS, LA., 2002. Degree of threat to the biological diversity in the Ilha Grande State Park (RJ) and guidelines for conservation. Brazilian Journal of Biology $=$ Revista Brasileira de Biologia, vol. 62, no. 3, p. 375-385. http://dx.doi.org/10.1590/S1519-69842002000300001. PMid:12530174

ASQUITH, NM., WRIGHT, SJ. and CLAUSS, MJ., 1997. Does mammal community composition control recruitment in Neotropical forests? Evidence from Panama. Ecology, vol. 78, no. 3, p. 941946. http://dx.doi.org/10.1890/0012-9658(1997)078[0941:DM CCCR]2.0.CO;2.

BERGALLO, HG., 1995. Comparative life-history characteristics of two species of rats, Proechimys iheringi and Oryzomys intermedius, in an Atlantic Rain Forest of Brazil. Mammalia, vol. 59, no. 1, p. 51-64. http://dx.doi.org/10.1515/mamm.1995.59.1.51.

BERGALLO, HG., 1996. The population dynamics of Proechimys iheringi and Orizomys intermedius in southeastern Brazil. Ciencia e Cultura, vol. 48, no. 3, p. 193-197.

BONVICINO, CR., DE OLIVEIRA, JA. and D'ANDREA, PS., 2008. Guia dos roedores do Brasil, com chaves para gêneros baseadas em caracteres externos. Rio de Janeiro: OPAS/WHO.

BONVICINO, CR., LINDBERGH, SM. and MAROJA, LS., 2002. Small non-flying mammals from conserved and altered areas of Atlantic forest and Cerrado: comments on their potential use for monitoring environment. Brazilian Journal of Biology $=$ Revista Brasileira de Biologia, vol. 62, no. 4B, p. 765-774. http:// dx.doi.org/10.1590/S1519-69842002000500005. PMid:12659027

BOZINOVIC, F., MUÑOZ, JLP. and CRUZ-NETO, AP., 2007. Intraspecific variability in the Basal metabolic rate: testing the food habits hypothesis. Physiological and Biochemical Zoology, vol. 80 , no. 4, p. 452-460. http://dx.doi.org/10.1086/518376. PMid: 17508340

BRITO, D. and FIGUEIREDO, MSL., 2003. Minimum viable population and conservation status of the Atlantic Forest spiny rat Trinomys eliasi. Biological Conservation, vol. 113, no. 1, p. 153-158. http://dx.doi.org/10.1016/S0006-3207(02)00344-0.

CARVALHO, FMV., PINHEIRO, PS., FERNANDEZ, FAS. and NESSIMIAN, JL., 1999. Diet of small mammals in Atlantic Forest fragments in southeastern Brazil. Revista Brasileira de Zoociências, vol. 1, no. 1, p. 91-101.

CASTRO, EBV. and FERNANDEZ, FAS., 2004. Determinants of differential extinction vulnerabilities of small mammals in Atlantic Forest fragments in Brazil. Biological Conservation, vol. 119, no. 1, p. 73-80. http://dx.doi.org/10.1016/j.biocon.2003.10.023.

CAUGHLEY, G. and KREBS, CJ., 1983. Are big mammals simply little mammals writ large? Oecologia, vol. 59, no. 1, p. 7-17. http://dx.doi.org/10.1007/BF00388066. PMid:25024141

CEBALLOS, G. and BROWN, JH., 1995. Global patterns of mammalian diversity, endemism and endangerment. Conservation Biology, vol. 9, no. 3, p. 559-568. http://dx.doi.org/10.1046/j.15231739.1995.09030559.x.

COHEN, JE., 1995. Population growth and earth's human carrying capacity. Science, vol. 269, no. 5222, p. 341-346. http://dx.doi. org/10.1126/science.7618100. PMid:7618100

COLAUTTI, RI. and MACISAAC, HJ., 2004. A neutral terminology to define "invasive" species. Diversity \& Distributions, vol. 10, no. 2, p. 135-141. http://dx.doi.org/10.1111/j.1366-9516.2004.00061.x. 
ERNEST, SKM., ENQUIST, BJ., BROWN, JH., CHARNOV, EL., GILLOOLY, JF., SAVAGE, VM., WHITE, EP., SMITH, FA., HADLY, EA., HASKELL, JP., LYONS, SK., MAURER, BA., NIKLAS, KJ. and TIFFNEY, B., 2003. Thermodynamic and metabolic effects on the scaling of production and population energy use. Ecology Letters, vol. 6, no. 11, p. 990-995. http:// dx.doi.org/10.1046/j.1461-0248.2003.00526.x.

ESBÉRARD, CEL., JORDÃO-NOGUEIRA, T., LUZ, JL., MELO, GGS., MANGOLIN, R., JUCÁ, N., RAÍCES, DSL., ENRICI, MC. and BERGALLO, H., 2006. Morcegos da Ilha Grande, Angra dos Reis, RJ, Sudeste do Brasil. Revista Brasileira de Zoociências, vol. 8 , no. 2 , p. 147-153.

FORSUM, E., HILLMAN, PE. and NESHEIM, MC., 1981. Effect of energy restriction on total heat production, basal metabolic rate, and specific dynamic action of food in rats. The Journal of Nutrition, vol. 111, no. 10, p. 1691-1697. PMid:6793699.

FONSECA, GAB., 1989. Small mammal species diversity in Brazilian tropical primary and secondary forests of different sizes. Revista Brasileira de Zoologia, vol. 6, no. 3, p. 381-422. http:// dx.doi.org/10.1590/S0101-81751989000300001.

JORDANO, P., GALETTI, M., PIZO, MA. and SILVA, WR., 2006. Ligando frugivoria e dispersão de sementes à biologia da conservação. In ROCHA, CFD., BERGALLO, HG., ALVES, MAS. and VAN SLUYS, M. (Eds.). Biologia da conservação: essências. São Carlos: Rima. p. 411-436.

KHAN, M., 2004. Effects of seed mass on seedling success in Artocarpus heterophyllus L., a tropical tree species of north-east India. Acta Oecologica, vol. 25, no. 1-2, p. 103-110. http://dx.doi. org/10.1016/j.actao.2003.11.007.

LEMOS, ERS., D'ANDREA, PS., BONVICINO, CR., FAMADAS, KM., PADULA, P., CAVALCANTI, AA. and SCHATZMAYR, HG., 2004. Evidence of hantavirus infection in wild rodents captured in a rural area of the state of São Paulo, Brazil. Pesquisa Veterinaria Brasileira, vol. 24, no. 2, p. 71-73. http://dx.doi. org/10.1590/S0100-736X2004000200004.

MCKINNEY, ML. and LOCKWOOD, JL., 1999. Biotic homogenization: a few winners replacing many losers in the next mass extinction. Trends in Ecology \& Evolution, vol. 14, no. 11, p. 450-453. http://dx.doi.org/10.1016/S0169-5347(99)01679-1. PMid:10511724

MCNAB, BK., 1986. The influence of food habits on the energetics of eutherian mammals. Ecological Monographs, vol. 56, no. 1, p. 1-19. http://dx.doi.org/10.2307/2937268.

MOONEY, HA. and CLELAND, EE., 2001. The evolutionary impact of invasive species. Proceedings of the National Academy of Sciences of the United States of America, vol. 98, no. 10, p. 54465451. http://dx.doi.org/10.1073/pnas.091093398. PMid:11344292

Núcleo de Estudos e Pesquisas em Alimentação - NEPA, 2011. Tabela Brasileira de Composição de Alimentos - TACO. 4th ed. Campinas: NEPA/UNICAMP.

OLIVEIRA, RR., 2002. Ação antrópica e resultantes sobre a estrutura e composição da Mata Atlântica na Ilha Grande, RJ. Rodriguésia, vol. 53, no. 82, p. 33-58.

PAGLIA, AP., FONSECA, GAB., RYLANDS, AB., HERRMANN, G., AGUIAR, LMS., CHIARELlO, AG., LEITE, YLR., COSTA, LP., SICILIANO, S., KIERULFF, MCM., MENDES, SL., TAVARES, VC., MITTERMEIER, RA. and PATTON, JL., 2012. Lista anotada dos mamíferos do Brasil. Belo Horizonte: Conservação Internacional.
PARDINI, R., DE SOUZA, SM., BRAGA-NETO, R. and METZGER, JP., 2005. The role of forest structure, fragment size and corridors in maintaining small mammal abundance and diversity in an Atlantic forest landscape. Biological Conservation, vol. 124, no. 2, p. 253-266. http://dx.doi.org/10.1016/j.biocon.2005.01.033.

PARDINI, R. and UMETSU, F., 2006. Pequenos mamíferos nãovoadores da Reserva Florestal do Morro Grande - distribuição das espécies e da diversidade em uma área de Mata Atlântica. Biota Neotropica, vol. 6, no. 2, p. 1-22. http://dx.doi.org/10.1590/ S1676-06032006000200007.

PAULY, D. and CHRISTENSEN, V., 1995. Primary production required to sustain global fisheries. Nature, vol. 374, no. 6519 , p. $255-257$. http://dx.doi.org/10.1038/374255a0

PHILLIPS, OL., 1997. The changing ecology of tropical forests. Biodiversity and Conservation, vol. 6, no. 2, p. 291-311. http:// dx.doi.org/10.1023/A:1018352405482.

PINTO, IS., LOSS, ACC., FALQUETO, A. and LEITE, YLR., 2009. Pequenos mamíferos não voadores em fragmentos de Mata Atlântica e áreas agrícolas em Viana, Espírito Santo, Brasil. Biota Neotropica, vol. 9, no. 3, p. 355-360. http://dx.doi.org/10.1590/ S1676-06032009000300030.

PRENTER, J., MACNEIL, C., DICK, JTA. and DUNN, AM., 2004. Roles of parasites in animal invasions. Trends in Ecology \& Evolution, vol. 19, no. 7, p. 385-390. http://dx.doi.org/10.1016/j. tree.2004.05.002. PMid:16701290

PREVEDELLO, JA., FERREIRA, P., PAPI, BS., LORETTO, D. and VIEIRA, MV., 2008. Uso do espaço vertical por pequenos mamíferos no Parque Nacional Serra dos Órgãos, RJ: Um estudo de 10 anos utilizando três métodos de amostragem. Espaço e Geografia, vol. 11, no. 1, p. 35-58

PYŠEK, P. and RICHARDSON, DM., 2010. Invasive Species, Environmental Change and Management, and Health. Annual Review of Environment and Resources, vol. 35, no. 1, p. 25-55. http://dx.doi.org/10.1146/annurev-environ-033009-095548.

RAHMAN, AKMM., HUQ, E., MIAN, AJ. and CHESSON, A., 1995. Microscopic and chemical changes occurring during the ripening of two forms of jackfruit (Artocarpus heterophyllus L.). Food Chemistry, vol. 52, no. 4, p. 405-410. http://dx.doi. org/10.1016/0308-8146(95)93290-8.

RIBEIRO, R. and MARINHO-FILHO, J., 2005. Estrutura da comunidade de pequenos mamíferos (Mammalia, Rodentia) da Estação Ecológica de Águas Emendadas, Planaltina, Distrito Federal, Brasil. Revista Brasileira de Zoologia, vol. 22, no. 4, p. 898-907. http://dx.doi.org/10.1590/S0101-81752005000400014.

SEBER, GAF., 1973. Estimation of animal abundance and related parameters. London: Griffin.

SHYAMALAMMA, S., CHANDRA, SBC., HEGDE, M. and NARYANSWAMY, P., 2008. Evaluation of genetic diversity in jackfruit (Artocarpus heterophyllus Lam.) based on amplified fragment length polymorphism markers. Genetics and Molecular Research, vol. 7, no. 3, p. 645-656. http://dx.doi.org/10.4238/ vol7-3gmr457. PMid:18752192

SIMBERLOFF, D. and VON HOLLE, B., 1999. Positive interactions of nonindigenous species: invasional meltdown? Biological Invasions, vol. 1, no. 1, p. 21-32. http://dx.doi. org/10.1023/A:1010086329619.

SLOBODKIN, LB., 2001. The good, the bad and the reified. Evolutionary Ecology Research, vol. 3, p. 1-13. 
SODHI, NS., PEH, KS-H., LEE, TM., TURNER, IM., TAN, HTW., PRAWIRADILAGA, DM. and DARJONO, 2003. Artificial nest and seed predation experiments on tropical southeast Asian islands. Biodiversity and Conservation, vol. 12, p. 2415-2433. http://dx.doi.org/10.1023/A:1025852214528.

VIEIRA, CM. and DINIZ-FILHO, JAF., 2000. Macroecologia de mamíferos neotropicais com ocorrência no Cerrado. Revista Brasileira de Zoologia, vol. 17, no. 4, p. 973-988. http://dx.doi. org/10.1590/S0101-81752000000400008.

VIEIRA, EM., PIZO, MA. and IZAR, P., 2003. Fruit and seed exploitation by small rodents of the Brazilian Atlantic forest. Mammalia, vol. 67, no. 4, p. 1-7. http://dx.doi.org/10.1515/ mamm-2003-0407.

VILÀ, M., ESPINAR, JL., HEJDA, M., HULME, PE., JAROŠÍK, V., MARON, JL., PERGL, J., SCHAFFNER, U., SUN, Y. and PYŠEK, P., 2011. Ecological impacts of invasive alien plants: a meta-analysis of their effects on species, communities and ecosystems. Ecology Letters, vol. 14, no. 7, p. 702-708. http:// dx.doi.org/10.1111/j.1461-0248.2011.01628.x. PMid:21592274

WILLIAMSON, M., 1999. Invasions. Ecography, vol. 22, no. 1, p. 5-12. http://dx.doi.org/10.1111/j.1600-0587.1999.tb00449.x.

WILLIAMSON, M. and FITTER, A., 1996. The characters of successful invaders. Biological Conservation, vol. 78, no. 1-2, p. 163-170. http://dx.doi.org/10.1016/0006-3207(96)00025-0.

ZEREGA, NJC., RAGONE, D. and MOTLEY, TJ., 2004. Complex origins of breadfruit (Artocarpus altilis, Moraceae): implications for human migrations in Oceania. American Journal of Botany, vol. 91, no. 5, p. 760-766. http://dx.doi.org/10.3732/ajb.91.5.760. PMid:21653430

ZEREGA, NJC., RAGONE, D. and MOTLEY, TJ., 2005. Systematics and Species Limits of Breadfruit (Artocarpus, Moraceae). Systematic Botany, vol. 30, no. 3, p. 603-615. http:// dx.doi.org/10.1600/0363644054782134. 